INGENIERÍA QUÍMICA

\title{
Preparación y caracterización del óxido de estaño y su uso como catalizador en la reacción de epoxidación de esteres grasos insaturados
}

CHEMICAL ENGINEERING

\section{Tin oxide preparation and characterization and use as a catalyst in the reaction of unsaturated fatty esters epoxidation}

\author{
Julián D. Urresta *§, Oscar González*, Jorge E. Rodríguez** \\ *Research Laboratory in Catalysis and Processes, LICAP. Universidad del Valle, Cali, Colombia \\ **Science and Technology Group on Ceramic Materials, CYTEMAC. Universidad del Cauca, \\ Popayán,
}

(Recibido: 14 de Diciembre del 2011 - Aceptado: 10 de Agosto del 2013)

\begin{abstract}
Resumen
La síntesis y la caracterización del óxido de estaño se estudiaron en este trabajo para evaluar su actividad catalítica en la reacción de epoxidación del metilricinoleato proveniente del aceite de ricino. La obtención del óxido se realiza por el método de precipitación controlada, encontrándose que se obtienen ventajas significativas al emplear soluciones acuosas de $\mathrm{SnCl}_{2} \cdot 2 \mathrm{H}_{2} \mathrm{O}$ como precursor. Su caracterización se efectuó por medio de las técnicas de DTA, TGA, DRX, encontrándose que para obtener un alto rendimiento hacia el sistema casiterita el valor de $\mathrm{pH}$ óptimo fue de 6.25, mientras que un $\mathrm{pH}$ de 8.0 conlleva hacia el sistema romarchita. En el caso de las técnicas de MEB y área superficial, se determinó que el tamaño de partícula encontrado estaba por debajo de los $50 \mathrm{~nm}$ con un área superficial de $19 \mathrm{~m}^{2} / \mathrm{g}$. El ester ricinoleico se obtuvo a partir del aceite empleando metilato de sodio como catalizador y seguidamente se hace reaccionar con peróxido de hidrógeno como agente oxidante y óxido de estaño para producir un epóxido. Finalmente, los productos de reacción se identifican por cromatografía de gases, encontrando que los óxidos de estaño son activos para la obtención de epóxidos con un mejor desempeño del sistema cristalino romarchita ( $\mathrm{SnO}$ ) principalmente hacia el metil-12-hidroxi-9, 10-epoxioctadecanoato (MHEOD).
\end{abstract}

Palabras clave: Casiterita, epoxioctadecanoato, epoxidación, óxido de estaño, romarchita.

\begin{abstract}
Tin oxide synthesis and characterization were studied in the present work in order to evaluate its catalytic activity in the reaction of methyl ricinoleate from castor oil. Oxide is obtained through the controlled precipitation method, and significant advantages are obtained when using water solutions of $\mathrm{SnCl}_{2} .2 \mathrm{H}_{2} \mathrm{O}$ as precursor. Its characterization was done using the techniques DTA, TGA, XRD, finding that in order to have high performance for the cassiterite system the optimum $\mathrm{pH}$ value was 6,25 whereas a $\mathrm{pH}$ of 8.0 was leading to the romarchite system. When using SEM techniques and a surface area, the size of the particle found was below $50 \mathrm{~nm}$ with a surface area $019 \mathrm{~m}^{2} / \mathrm{g}$. The ricinoleate ester was obtained from the oil using sodium methylate as catalyst and then making it react with hydrogen peroxide as oxidant agent and tin oxide to produce an epoxide. Finally, reaction products are identified through gas chromatography finding that tin oxides are active for obtaining epoxides with better performance of the romarchite crystal system (SnO) especially towards the methyl-12-hydroxi-9, 10-epoxioctadecanote (MHEOD).
\end{abstract}

Key words: Cassiterite, epoxi-octadecanoate, epoxidation, tin oxide, romarchite. 


\section{Introduction}

Epoxidation of oleochemical products has been the object of academic and industrial research (L.A. Rios et al, 2005, R. E. Harry-O'kuru et al, 2005), and derived products of vegetal oil have a commercial importance due to their application in plasticizers and polymer industries (U. Biermann et al, 2000). Vegetal oil can be directly epoxidized but not much work has been done in this regard. One work done is the one reported by V.V. Goud et al (2006a), obtaining in this case mono, di- and tri-epoxides. It is clear that the results depend on the reactive used and in this sense A. Corma et al (2007) have reported the use of formic acid in the presence of a heavy metal as complexing agent.

Epoxidation of fatty acids or methyl esters (FAME) coming from vegetal oils has been more studied, and in this case the double bond is attacked (V. V. Goud et al, 2009; J. Sepulveda et al, 2007; A. Campanella et al, 2008; E. Poli et al, 2009; and K. Wadumesthrige et al, 2009). This process requires an acid catalyst and generally mineral acids have been used because of their low cost, although there are works giving details about the catalyst attack on the oxiran ring during the reaction (L.H. Gan et al, 1992, F.A. Zaher et al, 1989, and A. Campanella and M.A. Baltanas, 2006).

It is worth mentioning the use of the aluminium oxide as catalyst in FAME's epoxidation, focusing on two alumina, one produced by the sol-gel process, and recognizing that both systems present very good catalytic activity in this reaction, though the alumina prepared by the sol-gel process is more efficient (J. Sepulveda, et al 2007). These authors state that after 24 hours the attainted conversion is of the order of $95 \%$, for a selectivity of $97 \%$, though after its reutilization is less active.

On the other hand, an oxidizing species such as the molecular oxygen has also been tested in the epoxidation of heavy olefins by J-R. Monnier (2001). What is shown in the study is that epoxidation of 1,3-butadiene is carried out with an $\mathrm{Ag}$ catalyst with the formation of an oxidizing species in situ (hydrogen peroxide from molecular O2). It is worth noticing that epoxidation of non-allylic species or sterically or kinetically-hindered ones require promoters such as $\mathrm{Cs}$ or $\mathrm{Rb}$ or some thallium salts to help in desorption of the epoxidized olefin. Other systems used successfully in the epoxidation reaction are the $\mathrm{Cu} / \mathrm{V}$ by L. Yang et al (2010), Ag by J-R Monnier (2001) a polimetacrilate peroxotugstene or heteropolioxometaltes by $\mathrm{G}$. Gelbard et al (2000) and Z. Xi et al (2001), or even complex Mn salt (III) and Mo (IV) by T. Luts et al (2007). The use of a tungsten-based solid has been reported, the phosphotungstate, but this time evaluating the absence of solvent over the selectivity in epoxidation (E. Poli et al, 2009).

Researchers conclude that the catalyst produces a selective transformation of cismethyl oleate in cis-epoxioleate under much more cleaner conditions, due to the use of a stoichiometric amount of of hydrogen peroxide and the suppression of solvent in the medium of reaction. Such a result is probably due to a synergic effect between the hydrogen peroxide and the air oxygen at a low temperature $313 \mathrm{~K}$, though they also state the possibility of a low dimerization of the methyloleate due to catalyst saturation because of the air oxygen.

As far as the tin oxide is concerned, this is a system with good affinity with the carbonyl and carboxyl functions, it is confirmed that itenhances its capacity when a second element is incorporated (P.J. Smith, 1998). Among the incorporated elements for such purpose there is phosphorus, antimony, vanadium, chromium, molybdenum, manganese, and copper. These systems have been used to promote the oxidation of carbon monoxide, sulfur dioxide and saturated and unsaturated hydrocarbons, as well as other organic compounds. Palladium can also be used in methane oxidation (K. Skizawa et al, 2000) and for the oil transesterification processes and for dimethyloxalate, where tin oxide is mixed with other solids, such as $\mathrm{SiO}_{2}, \mathrm{ZnO}$, and $\mathrm{TiO}_{2}$ (J. Urresta et al, 2000, S.Wang et al, 2004 and S. Verdier et al, 2003). Finally, in the present work a tin oxide type romarchite and casserite was synthesized, through the method of controlled precipitation. The solid obtained was used in the methyl esters epoxidation reaction resulting from the castor oil plant with hydrogen peroxide as oxidizing agent. 


\section{Experimental}

\subsection{Materials and Reagents}

Reactives used in the present work such as $\mathrm{KOH}, \mathrm{SnCl}_{2} * 2 \mathrm{H}_{2} \mathrm{O}$, and $\mathrm{Al}_{2} \mathrm{O}_{3}$ were obtained from Mallinckrot, the acetic acid from Aldrich, the castor-oil acid in a composition of $90 \%$ in ricinoleic acid form Genquímicos Ltda, and chloroform, ethanol, sodium anhydrous sulfate, sodium methoxide, tert-butanol, hydrogen peroxide, ammonium hydroxide, and 1-fenilethanol from Merck. Tin oxide was obtained by the controlled precipitation method (CPM), using $\mathrm{SnCl}_{2}$ as starting material and via the above mentioned process by Avila and Rodriguez-Paez (2009).

\section{2 Characterization of solids}

To obtain the crystalline phases a Phillips PW1830/40 diffractometer with Co anode (k $=1,790 \mathrm{~A}$ ) and an iron filter, operating at $40 \mathrm{kV}$ and $30 \mathrm{~mA}$, at a pace of $0.02^{\circ}$ and a fixed time of 0.3 second for a range of 20 to $80^{\circ}$ was used. Microstructural characterization of solids was determined via a SEM electronic microscope (JEOL 1200 EX) operating at $80 \mathrm{keV}$. Powders were previously dried at a furnace at $80^{\circ}$ for 24 hours and finally macerated in an agate mortar. Solids were also characterized with the differential thermic and gravimetric analysis (Shimadzu TG / Dt - 50) in order to determine the endo- and exothermic processes that could be performed during thermic treatment. Analysis was carried out in the presence of dry air $(7 \mathrm{~L} /$ min flux) at a heating speed of $10^{\circ} \mathrm{C} / \mathrm{min}$ with $\mathrm{Al}_{2} \mathrm{O}_{3}$ as reference material.

\subsection{Preparation of methyl ester from castor-oil}

To remove free fatty acids in the oil a treatment is performed with a concentrated ethanol solution of $\mathrm{KOH}$ at a temperature of $65^{\circ} \mathrm{C}$, during 2 hours. The mixture obtained is warmed in backflow during 4 hours and while it is hot it is diverted to a separation funnel. After an $\mathrm{HCl}$ diluted solution of $0.1 \mathrm{~N}$ is added, for the separation of the aqueous and organic phases, and the respective phase is extracted. To this phase $5 \mathrm{~mL}$ of distilled water were added and an emulsion was then formed and treated with a similar quantity of chloroform/ ethanol 50/50 and a cooling-down period was allowed for the separation of the phases. To the organic phase selected solvent is evaporated, and then a small quantity of sodium anhydrous sulfate is added to absorb the remaining water. For the preparation of methyl esters of the castor-oil plant, to the previous product was added methanol in a relationship of $1 / 6$ with sodium methoxide in methanol as catalyst. The mixture was put in backflow during 4 hours at $65^{\circ} \mathrm{C}$ and a washing process was performed as it was described before.

\subsection{Epoxidation Reaction}

In a three-neck flask with $50 \mathrm{ml}$ capacity and equipped with a condenser, approximately $3 \mathrm{~g}$ $(\sim 10 \mathrm{mmol})$ of methyl ester were placed. Then, $1.2 \mathrm{ml}$ of tert-butanol was added as solvent and immediately after $2 \mathrm{ml}$ of a homogenized solution at $6 \%$ of hydrogen peroxide $\left(\mathrm{H}_{2} \mathrm{O}_{2}\right)$ were added in 1-fenilethanol, the latter being added to stabilize the hydrogen peroxide and lastly $0.1 \mathrm{~g}$ of catalyst is added. The solution was heated to reflux at $10^{\circ} \mathrm{C}$ with constant agitation during 7 hours. The following conditions were also tested: reaction time (2, $4,6,7,8$, and 10 hours), reaction temperature $\left(110\right.$ and $\left.130^{\circ} \mathrm{C}\right)$, and heat treatment in muffle to $\mathrm{SnO}$ catalyst at $2 \%$ by mass $(100,200,300$, 450 , and $\left.600^{\circ} \mathrm{C}\right)$ and the quantity of oxidizing solution $(1,2$, and $3 \mathrm{ml}$ of $6 \%$ solution oh hydrogen peroxide in 1-fenilethanol). After completing the reaction time, catalyst was stirred for centrifugation.

\subsection{Chromatographic Analysis}

All compounds have been analyzed using a CG Hewlett Packard 6890 with a FID detector and equipped with a HP-\% column $(30 \mathrm{mx} 0.32 \mathrm{mmx} 0.25 \mu \mathrm{m})$. Injector and detector temperatures were $260^{\circ}$ and $280^{\circ} \mathrm{C}$ respectively. Carrier gas was helium and the furnace temperature was $50^{\circ} \mathrm{C}$ for $3 \mathrm{~min}$ and then it increased to $10 \mathrm{C} / \mathrm{min} \mathrm{C}$, and keeping this temperature for $10 \mathrm{~min}$. Dodecane was used as internal standard. 


\section{Results and discussion}

\subsection{Synthesis and characterization of tin oxide, through the determination of solid crystalline phases}

Figure 1 shows $\mathrm{pH}$ change when doing titration with ammonium hydroxide of $\mathrm{SnCl}_{2} * 2 \mathrm{H}_{2} \mathrm{O}$ dissolutions using acetic acid and ethanol as solvent. Through addition of $\mathrm{SnCl}_{2}$ in acetic acid, it is expected that the mains species in solution would be anionic compounds, because of the complexing nature of the ethyl anion; the most important species in the solution would be the tin tricarboxylate ones (II) $\left[\mathrm{Sn}\left(\mathrm{RCO}_{2}\right)_{3}\right]$.
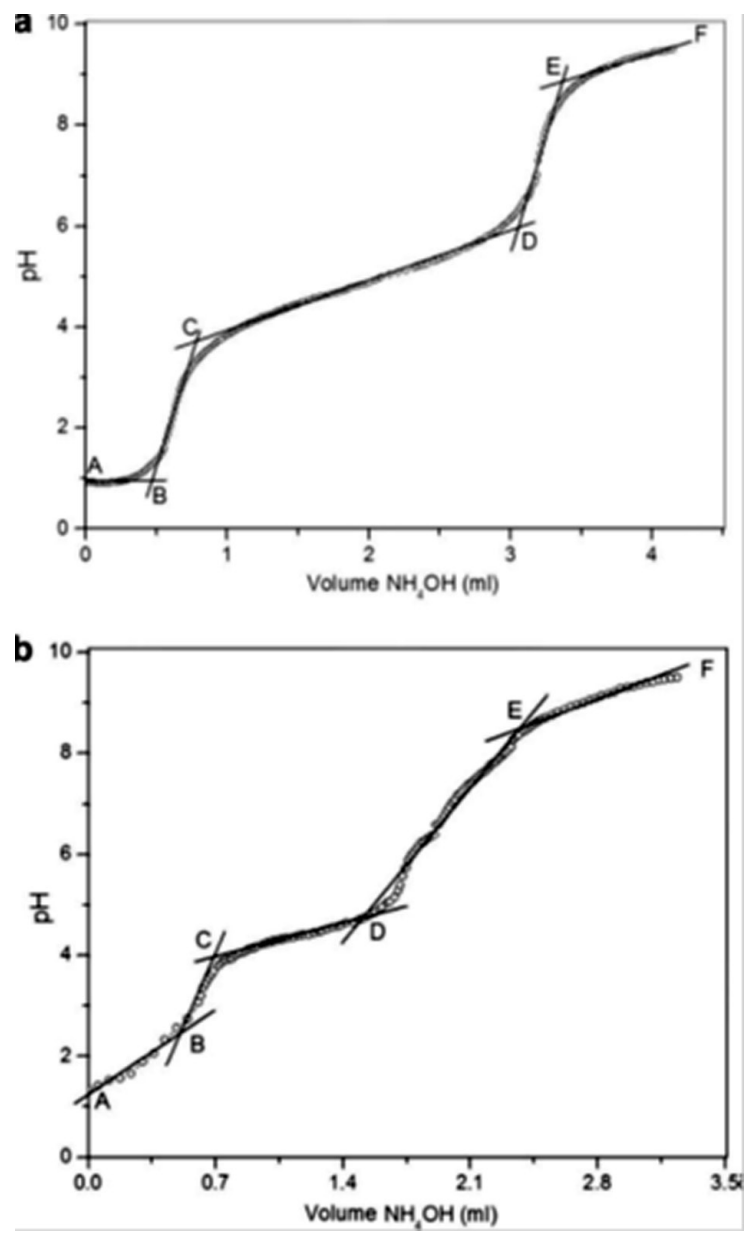

Figure 1. Potentiometric titration curves of $0.1 \mathrm{M}$ solution $\mathrm{SnCl}_{2} \cdot 2 \mathrm{H}_{2} \mathrm{O}$ in: (a) Acetic acid and (b) Ethanol as solvent.

When analyzing the behavior of the $\mathrm{SnCl}_{2}$ $\mathrm{CH}_{3} \mathrm{COOH}$ system through the addition of $\mathrm{NH}_{4} \mathrm{OH}$ in figure 1, we can observe five regions: two with significant $\mathrm{pH}$ changes in $(\mathrm{BC}$ and $\mathrm{DE})$ and three plateaus $(\mathrm{AB}, \mathrm{CD}, \mathrm{EF})$. Region
AB corresponds to the $\mathrm{H}^{+}$ion neutralization produced by the reaction (1), forming less stable compounds and the tricarboxylates-stannates already mentioned.

The third CD region represents high consumption of $\mathrm{OH}$ ions due to dissolvent neutralization (Reaction (1)) and the hydrolysis of the compounds formed in previous phases.

$$
\begin{aligned}
& \mathrm{CH}_{3} \mathrm{COOH}+\mathrm{NH}_{4} \mathrm{OH} \rightarrow \mathrm{CH}_{3} \mathrm{COONH}_{4}+\mathrm{H}_{2} \mathrm{O} \\
& \text { Reaction (1) }
\end{aligned}
$$

In this region there are also polynuclear species $\left[\mathrm{Sn}_{2}(\mathrm{OH})_{4} \mathrm{O}\right]_{2}^{-}$, where the oxygen bridge makes it possible for the pyramidal structure to get stable $\mathrm{Sn}(\mathrm{II})$. Polynuclear species such as $\left[\mathrm{Sn}_{2}(\mathrm{OH})_{2}\right]_{2}{ }^{+}$, $\left[\mathrm{Sn}_{3}(\mathrm{OH})_{4}\right]_{2}^{+}$and $\left[\mathrm{SnO}(\mathrm{OH})_{2}\right]_{2}^{-}$can be formed as products of the reactions of hydrolization reaction $\mathrm{SnCl}_{2}$ (E. Ararat, 2007). The union of these polynuclear species would allow the embryos' growth which, upon reaching the critical size, would develop the nuclei of the solid phase.

The development of the nuclei in the DE region is the most important part of the process since the first ever precipitate appears at $\mathrm{pH}$ 6.2, right at the start of this region. In the last $\mathrm{EF}$ region, $\mathrm{pH}$ stabilization corresponds to the system saturation. Here, the tin-oxy type complexes must prevail, benefiting the $\mathrm{SnO}$ formation, as indicated on the DRX and FTIR analysis. Moreover, when ethanol is employed as a solvent (Fig 1(b)), five similar regions are observed, as shown in figure 1 (a). Through this system, the following reactions may occur:

$$
\mathrm{SnCl}_{2}+2 \mathrm{H}_{2} \mathrm{O} \underset{\text { Reaction (2) }}{\stackrel{\mathrm{C}_{2} \mathrm{H}_{5} \mathrm{OH}}{\longrightarrow} \mathrm{Sn}(\mathrm{OH})_{2}+2 \mathrm{H}^{+}+2 \mathrm{Cl}^{-}}
$$

In the $\mathrm{AB}$ region an almost linear increase in $\mathrm{pH}$ is shown due to the neutralization of $\mathrm{H}+$ in the system, representing the dissolving of tin chloride (II). The second BC area represents the formation of soluble complexes originated in hydrolysis reactions (Reaction 2). In the third $\mathrm{CD}$ region, the vast consumption of $\mathrm{OH}-$ is due to the condensation reaction that lead to the polynuclear species such as $\left[\mathrm{Sn}_{2}(\mathrm{OH})_{2}\right]^{2+}$, $\left[\mathrm{Sn}_{3}(\mathrm{OH})_{4}\right]^{2+} \mathrm{y}\left[\mathrm{SnO}(\mathrm{OH})_{2}\right]^{2-}$. The last EF region 
shows the saturation dissolving due to the excess of ammonium hydroxide in the system of ethanol chloride-Sn (II).

Figure 2(a) shows the $\mathrm{X}$-ray diffractogram of the solid obtained from the $\mathrm{SnCl}_{2}-\mathrm{CH}_{3} \mathrm{CO}_{2} \mathrm{H}$ at $\mathrm{pH}$ 8.0, where a crystalline romarchite phase is mainly found according to the JCPDS 06-0395 files. A small formation of cassiterite $\mathrm{SnO}_{2}$ (JCPDS 21$1250)$ is observed in the unwashed system. These results allow concluding that it is possible to obtain $\mathrm{SnO}$ by employing acetic acid as a solvent with a small formation of $\mathrm{SnO}_{2}$. When the cleansings are done with an aqueous dissolution of $0.05 \mathrm{M}$ in diethylamine, the presence of the crystalline romarchite phase is exclusively observed. Figure 2(b) shows the diffractograms of prepared solids in ethanol at $\mathrm{pH} 6.5$, being observed that in the unwashed sample an amorphous solid with the presence of an incipient formation of cassiterite $\left(\mathrm{SnO}_{2}\right)$ is found. Furthermore, when the elimination of the chlorines with the diethylamine solution is carried out, the crystallization of a romarchite hydrate is favored $\mathrm{SnO}^{*} 2 \mathrm{H}_{2} \mathrm{O}$ (JCPDS 07-0194). The presence of other peaks is also observed, but
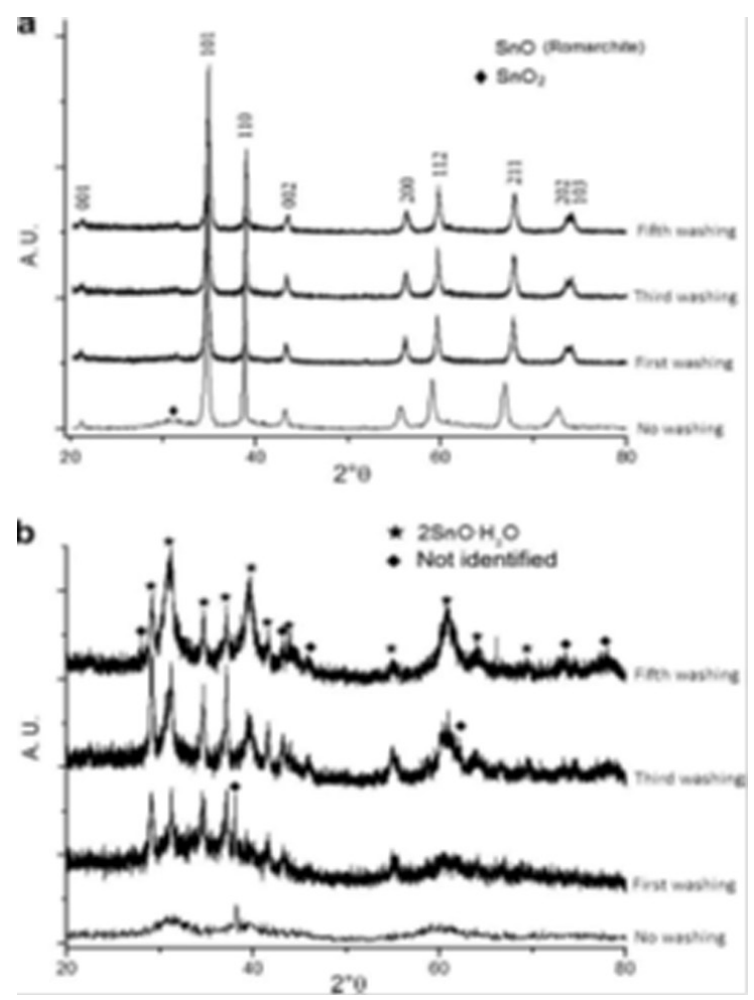

Figure 2. XRD patterns of calcined solids at $600^{\circ} \mathrm{C}$ and obtained by means of: (a) $\mathrm{SnCl}-\mathrm{CH}_{3} \mathrm{CO}_{2} \mathrm{H}$, and (b) $\mathrm{SnCl}-\mathrm{CH}_{3} \mathrm{CH}_{2} \mathrm{OH}$, both with and without washing with diethylamine solution $0.05 \mathrm{M}$. they are not related to any reference compound in particular. Of the previous results, it can be concluded that when using acetic acid as a solvent and taking the $\mathrm{pH}$ to 8.0 , a crystalline romarchite phase is obtained, whilst upon employing ethanol as a solvent and afterward taking the $\mathrm{pH}$ to 6.5 the crystalline phase obtained in this simple after thermal treatment to $400{ }^{\circ} \mathrm{C}$ was cassiterite.

\subsection{Morphology and Size of the Particles}
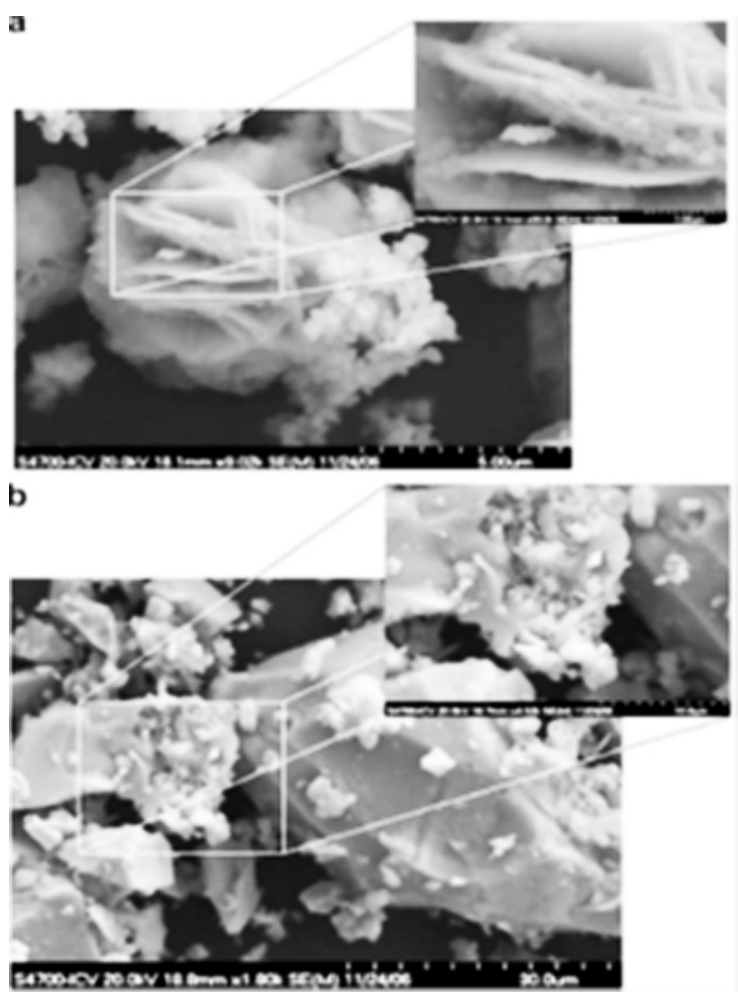

Figure 3. SEM images obtained from the solid $\mathrm{SnO}$ treated at $600{ }^{\circ} \mathrm{C}$ for $2 \mathrm{~h}$ : (a) $\mathrm{SnCl}-\mathrm{CH}_{3} \mathrm{CO}_{2} \mathrm{H}, y$ (b) $\mathrm{SnCl}-\mathrm{CH}_{3} \mathrm{CH}_{2} \mathrm{OH}$.

Figure 3 shows particles of an irregular shape with the presence of agglomerates of $200 \mu \mathrm{m}$. The primary particles have a smaller size of 2 $\mu \mathrm{m}$. Specifically in Figure 3(a) a micrometric cluster flower type $\mathrm{SnO}$ is observed, obtained by the Sn (II) salt in acetic acid. The formation of polycrystalline leaves made of spherical nanoparticles. In Fig. 3(b) a cluster with a dense structure and of a micrometric size is shown, obtained by the $\mathrm{SnCl}_{2}$-etanol system.

\subsection{Thermic Analysis of Solids}

Figure 4(a) shows the DTA/TGA curve of the precipitate solids at $\mathrm{pH} 8.0$ with acetic acid as 
a solvent. In the TGA curve, the loss of a small weight below the $100^{\circ} \mathrm{C}$ is due to the loss of adsorbed water. The weight loss between 200$250^{\circ} \mathrm{C}$, as is with the exothermic peak in the DTA curve, might be associated with water and ammonia, chemically and structurally absorbed. At $300^{\circ} \mathrm{C}$ there is weight loss associated with the exothermic peak in the DTA curve which indicates organic matter combustion and the oxidation of the hydroxyl groups (F. Lui et al, 2005). The TGA curve at higher temperatures between 400 and $700^{\circ} \mathrm{C}$ may be associated with the $\mathrm{SnO}$ oxidation or with the $\mathrm{SnO}$ disproportion expressed in the following equations:

$$
\begin{gathered}
2 \mathrm{SnO}+\mathrm{O}_{2} \rightarrow 2 \mathrm{SnO}_{2} \\
\text { Reaction (3) }
\end{gathered}
$$

Nevertheless, it must be known that tin may be present during the thermic treatment, due to stoichiometric reactions of disproportionation as shown by H. Giefersa et al. (2005).

$$
\underset{\text { Reaction (4) }}{2 \mathrm{SnO} \rightarrow \mathrm{SnO}_{2}+\mathrm{Sn}}
$$
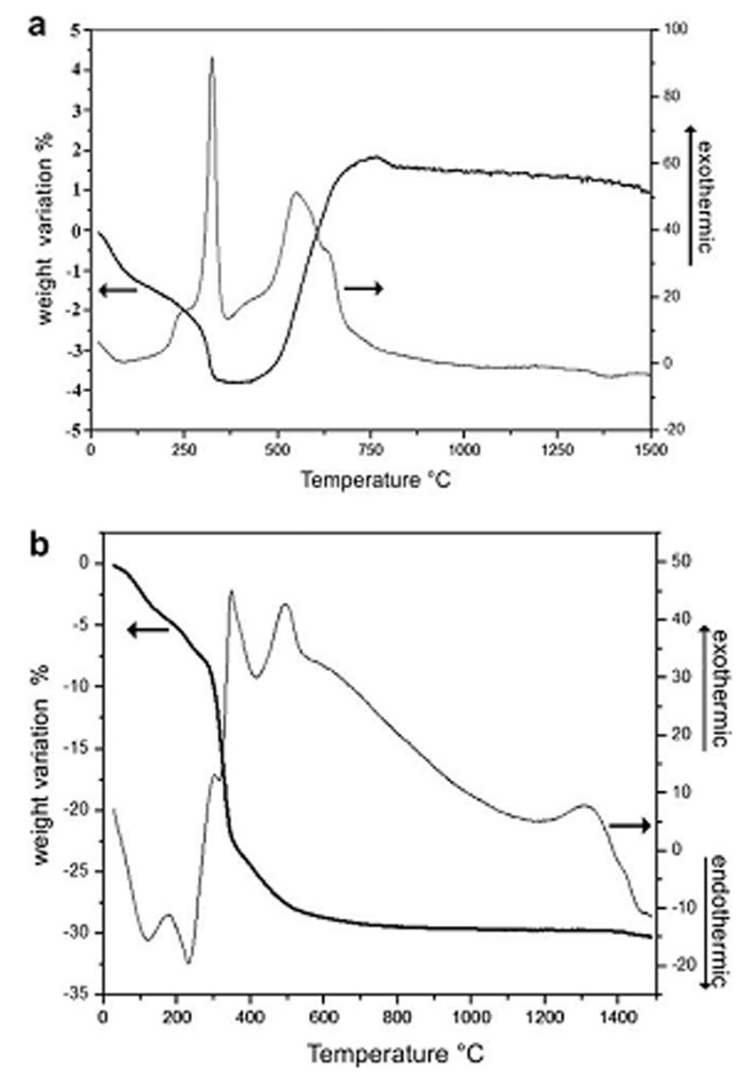

Figure 4. DTA curves and corresponding to the solids obtained from the solution of $\mathrm{SnCl}_{2} * 2 \mathrm{H}_{2} \mathrm{O}$ in TGA: (a) acetic acid at $\mathrm{pH}=8.0$ and (b) ethanol at $\mathrm{pH}=6.5$.

$$
\begin{gathered}
3 \mathrm{SnO} \rightarrow \mathrm{Sn}_{2} \mathrm{O}_{3}+\mathrm{Sn} \\
\text { Reaction }(5) \\
\underset{2}{2 \mathrm{Sn}_{2} \mathrm{O}_{3} \rightarrow 3 \mathrm{SnO}_{2}+\mathrm{Sn}} \\
\quad \text { Reaction (6) }
\end{gathered}
$$

The DTA and TGA curves in Fig. 4(b) correspond to the solid obtained from $\mathrm{SnCl}_{2}-\mathrm{C}_{2} \mathrm{H}_{5} \mathrm{OH}$ a $\mathrm{pH}$ 6.5 system. $9 \%$ of the weight loss between 110 and $250^{\circ} \mathrm{C}$ is associated with two endothermic peaks of the DTA curve. This corresponds to chemically connected water. The second weight loss (11\%) at $250-400^{\circ}$ would be associated with two narrow exothermic peaks which can correspond to organic matter decomposition (particularly ethoxy groups). Above the $400^{\circ} \mathrm{C}$ a constant weight loss is obtained and the DTA peaks may be associated to crystallization material.

\subsection{Determining Composition and Characteristics of Castor Oil and Methyl Ester}

Table 1 shows the values of the different determined rates for the commercial castor oil.

The physical state shows us that the liquid oil possesses a light yellow coloring and is soluble

Table 1. Specific values for castor oil and its composition.

\begin{tabular}{lc}
\hline Acid value (mg/lg sample) & 0.808 \\
Saponification value (mg/lg sample) & 312.66 \\
Iodine value (g/100g sample) & 13.06 \\
Peroxide value (meq/1000g) & 2.74 \\
Physical state & Yellow clear \\
viscous liquid \\
Solubility & Ethanol 98\%, \\
& chloroform \\
Melting point & $99 \%$ \\
& $5.5{ }^{\circ} \mathrm{C}$ \\
\hline Methyl ester & \\
& Percentage \\
\hline C16:0 & \\
C18:1 & 0.5 \\
C18:1-OH & 1.3 \\
& 2.3 \\
\hline & 6.8 \\
& 89.0 \\
\hline
\end{tabular}


Table 2. Epoxidation of methyl esters of castor oil

\begin{tabular}{cccccc}
\hline Catalyst & Conversion (\%) & \multicolumn{4}{c}{ Selectivity to epoxide } \\
& & MEOD & MEODECEN & MDEOD & MHEOD \\
\hline Al2O3 & 9.5 & -- & 3.0 & 9.9 & 87.1 \\
$\mathrm{SnO}$ & 39.0 & 2.4 & 4.0 & 8.0 & 85.7 \\
$\mathrm{SnO} 2$ & 5.1 & -- & 3.5 & 6.5 & 90.5 \\
\hline
\end{tabular}

Reaction temperature $T_{r}=110^{\circ} \mathrm{C}$, reaction time $t_{r}=7 \mathrm{~h}$, tert-butanol as solvent, $2 \mathrm{ml}$ of a homogenized solution 6\% hydrogen peroxide $\left(\mathrm{H}_{2} \mathrm{O}_{2}\right)$ in 1-phenylethanol, catalyst mass $m_{m}=0.1 \mathrm{~g}$ of catalyst. Methyl-12-hydroxy-9,10epoxyoctadecanoate (MHEOD), Methyl-9,10- epoxyoctadecanoate (MEOD), Methyl-9,10- epoxyoctadecanoate (MEODECEN), Methyl-9,10,12,13-diepoxyoctadecanoate (MDEOD).

in ethanol and chloroform, due to the $\mathrm{OH}$ group present in the ricinoleic acid. The value of the acidity rate $(0.808)$ indicates that the oil has a low quantity of free fatty acid, so it can be assumed that the oil, in a great percentage, is found in a triglyceride state and this is demonstrated with the value of the saponification or esterification rate (312.66). The seemingly low iodine rate (13.06) for the composition of the castor oil might be due to sterical impediment. The peroxide rate determines the quality of the oil in terms of its state of rancidity and for this case it is 2.74. This low value shows that the oil is in good state and, therefore, the double bonds are not altered.

The ester stemming from the castor oil presents 5 products (see table 2 ), considering the majority product the ester of the ricinoleic acid.

\subsection{Study of the Reaction of the Epoxidation of the Methyl Ester}

Firstly the epoxidation reaction of the methyl esters is carried on with (table 3$)$, employing $3 g(\sim 10$ mmol) of methyl ester, $1.2 \mathrm{ml}$ of tert-butanol as a solvent, $2 \mathrm{ml}$ of a $6 \%$ hydrogen peroxide $\left(\mathrm{H}_{2} \mathrm{O}_{2}\right)$ homogeneous mixture in 1-phenylethanol and 0.1 $\mathrm{g}$ of catalyst, with a reaction temperature of $110^{\circ} \mathrm{C}$ in constant mixing for 7 hours. For this reaction, the solids obtained through the method of controlling precipitation, (Romarchite (SnO), Cassiterite $\left(\mathrm{SnO}_{2}\right)$ ), and the $\mathrm{Al}_{2} \mathrm{O}_{3}$ as a reference catalyst.

Comparing the different catalysts, it can be observed that the Romarchite ( $\mathrm{SnO}$ ) presents the biggest conversion. Regarding Aluminium oxide $\left(\mathrm{Al}_{2} \mathrm{O}_{3}\right)$, it has a low conversion percentage, but it also generates products of epoxidation. According to the obtained results, it were obtained methyl-12hydroxy-9, 10-epoxyoctadecanoate (MHEOD), methyl-9,10-epoxyoctadecanoate (MEOD), methyl-9, 10-epoxyoctadecanoate (MEODECEN) y methyl-9, 10, 12, 13-diepoxyoctadecanoate (MDEOD). The most efficient solid for the epoxidation reaction is the romarchite and it is thus chosen as a catalyst to continue with the study.

\subsection{The effect of the $\mathrm{SnO}$ calcination temperature on the epoxidation reaction}

In table 4 the results of the epoxidation results

Table 3. Effect of $\mathrm{SnO}$ calcination temperature on the reaction epoxidation.

\begin{tabular}{|c|c|c|c|c|}
\hline \multirow{2}{*}{$\begin{array}{c}\text { Calcination } \\
\text { temperature }{ }^{\circ} \mathrm{C}\end{array}$} & \multirow{2}{*}{$\begin{array}{c}\text { Conversion } \\
(\%)\end{array}$} & \multicolumn{3}{|c|}{ Selectivity to epoxide } \\
\hline & & $M E O D$ & $\begin{array}{l}\text { MEODECEN } \\
+ \text { MDEOD }\end{array}$ & MHEOD \\
\hline 100 & 5.6 & -- & -- & 100 \\
\hline 200 & 21.8 & -- & 10.0 & 90.0 \\
\hline 300 & 22.9 & -- & -- & 100 \\
\hline 450 & 39.0 & 2.4 & 11.9 & 85.7 \\
\hline 600 & 76.8 & -- & 9.5 & 90.5 \\
\hline
\end{tabular}

Reaction temperature $T_{r}=110^{\circ} \mathrm{C}$, reaction time $t_{r}=7 \mathrm{~h}$, tert-butanol as solvent, $2 \mathrm{ml}$ of a homogenized solution $6 \%$ hydrogen peroxide $\left(\mathrm{H}_{2} \mathrm{O}_{2}\right)$ in 1-phenylethanol, catalyst mass $m_{\text {cata }}=0.1 \mathrm{~g}$ of catalyst. 

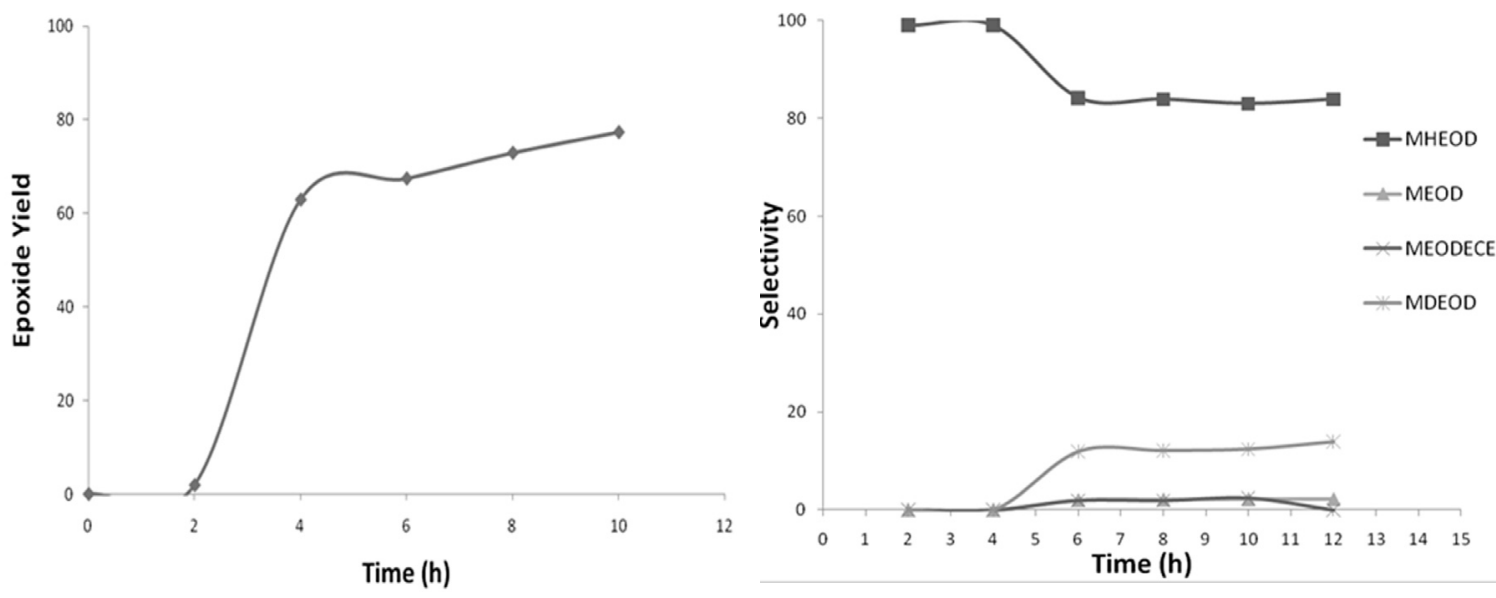

Figure 5. Epoxidation reaction with $\mathrm{SnO}$ calcined at $600^{\circ} \mathrm{C}$. ( a) yield ( b ) Selectivity. Reaction conditions: Temperature $T_{R x}=130^{\circ} \mathrm{C}$, tert-butanol as solvent, $2 \mathrm{ml}$ of hydrogen peroxide $\left(\mathrm{H}_{2} \mathrm{O}_{2}\right) 6 \%$ 1-phenylethanol, mass of catalyst $m_{\text {cata }}=0.1 \mathrm{~g}$.

for the $\mathrm{SnO}$ at different calcination temperatures are shown. In the figure 5 it can observe that the efficiency increases in the measure that the temperature of the thermic treatment does so as well with a slight exception at $300^{\circ} \mathrm{C}$, being the thermic treatment at $600^{\circ} \mathrm{C}$ the one that presents the highest conversion percentage in the epoxidation reaction. The selectivity remains practically constant for the 5 tested thermic treatments, being the majority product the methyl-12-hydroxy-9, 10-epoxyoctadecanoate (MHEOD).

When evaluating the behavior of the solid processed at $600^{\circ} \mathrm{C}$ regarding time and to a reaction temperature of $130^{\circ} \mathrm{C}$, an increase is observed in the efficiency percentage in the measure that the reaction time increases with an almost constant selectivity. It can also be observed that the reaction at $130^{\circ} \mathrm{C}$ tends to degrade the products after the 12 hours of reaction, given that a coloring in the reaction products is seen.

\subsection{The effect of oxidizing mixture on the efficiency of the epoxidation reaction}

Under the established conditions different quantities of oxidizing mixture were tested for two of the worked on temperatures, 110 and $130^{\circ} \mathrm{C}$. The table 4 shows the principal results obtained..

The results for $110^{\circ} \mathrm{C}$ indicate that the enzyme substrate/oxidizing agent relationship is directly proportional to the conversion factor, and when working with a temperature of $130^{\circ} \mathrm{C}$, a more important conversion is observed, but similar

Table 4. Effect of the amount of oxidizing solution on $\mathrm{SnO}$ activity against the epoxidation reaction of the methyl ester from castor oil.

\begin{tabular}{|c|c|c|c|c|c|c|}
\hline \multirow{2}{*}{$\begin{array}{c}\text { Oxidizing } \\
\text { solution in } m L\end{array}$} & \multirow{2}{*}{$\begin{array}{l}\text { The reaction } \\
\text { temperature } \\
\text { in }{ }^{\circ} \mathrm{C}\end{array}$} & \multirow{2}{*}{$\begin{array}{c}\text { Conversion } \\
\text { (\%) }\end{array}$} & \multicolumn{4}{|c|}{ Selectivity to epoxide } \\
\hline & & & MEOD & MEODECEN & MDEOD & MHEOD \\
\hline \multirow{2}{*}{1} & 110 & 25.6 & 0 & 0 & 9.2 & 90.8 \\
\hline & 130 & 52.9 & 0 & 0 & 14.3 & 85.7 \\
\hline \multirow{2}{*}{2} & 110 & 76.8 & 0 & 0 & 9.5 & 90.5 \\
\hline & 130 & 66.0 & 1.7 & 2.0 & 10.9 & 85.4 \\
\hline \multirow{2}{*}{3} & 110 & 75.6 & 1.5 & 2.9 & 8.1 & 87.5 \\
\hline & 130 & 96.2 & 1.5 & 2.4 & 10.5 & $84.7 *$ \\
\hline
\end{tabular}

*Other products possibly forming epoxide decomposition products found. Reaction conditions: Temperature $\left(T_{R x}\right)=$ 110 and $130^{\circ} \mathrm{C}$, tert-butanol as the solvent, $1,2,3 \mathrm{~mL}$ of hydrogen peroxide $\left(\mathrm{H}_{2} \mathrm{O}_{2}\right) 6 \%$ 1-phenylethanol, catalyst mass $\left(m_{\text {catd }}\right)=0.1 \mathrm{~g}$. 
selectivity than found at $110^{\circ} \mathrm{C}$. This last behavior seems logical because in the measure that the enzyme substrate/oxidizing agent relationship increases there will be greater conversion percentage, though the efficiency of the catalyst, which may be affected by the concentration of the oxidizing agent mixture, is not to be dismissed. Thus, the reaction needs a quantity of $3 \mathrm{~mL}$ of the oxidizing agent.

\section{Conclusions}

Based on the obtained results, it can be concluded that for the synthesis of the tin oxide the type of solvent has an influence on the synthesis process and it affects the morphology and the size of the particle. Indeed, when employing acetic acid, the presence of polynuclear species $\left[\mathrm{Sn}_{2}(\mathrm{OH})_{4} \mathrm{O}\right]^{2-}$ is favored, in which the oxygen bridge would allow the stability of the pyramidal structure $\mathrm{Sn}(\mathrm{II})$ and polynuclear species like $\left[\mathrm{Sn}_{2}(\mathrm{OH})^{2}\right]^{2+}$, $\left[\mathrm{Sn}_{3}(\mathrm{OH})_{4}\right]^{2+}$ and $\left[\mathrm{SnO}(\mathrm{OH})_{2}\right]^{2-}$ could be formed too. The union of these polynuclear species would allow the growth of the embryos which, upon reaching critical size, would develop tin-oxy type complexes, benefitting the formation of $\mathrm{SnO}$.

Regarding the epoxidation reaction, the efficiency of the romarchite was determined, with the solid treated thermically at $600^{\circ} \mathrm{C}$ being the most active one. The reaction temperature of $130^{\circ} \mathrm{C}$ and of an oxidizing mixture of hydrogen peroxide is necessary to epoxide the ricinoleic ester effectively towards the methyl-12hydroxy-9, 10-epoxy octadecanoate (MHEOD) ( $85 \%$ selectivity), with a $96 \%$ conversion. Shown was also the need to add $3 \mathrm{~mL}$ of oxidizing mixture of hydrogen peroxide $\left(\mathrm{H}_{2} \mathrm{O}_{2}\right)$ at $6 \%$ in 1-phenylethanol to obtain better results.

\section{Acknowledgements}

Acknowledgements go to COLCIENCIAS and to the Research Vice-chancellor (VRI) of the University of Valle for economically financing this project.

\section{References}

Ararat C., Mosquera A., Parra R., Castro M.S., \& Rodríguez-Páez J.E., (2007). Synthesis of $\mathrm{SnO}_{2}$ nanoparticles through the controlled precipitation route. Materials Chemistry and Physics 101, 433-440.

Ávila H.A., \& Rodríguez-Páez J.E., (2009). Solvent effects in the synthesis process of tin oxide, Journal of Non-Crystalline Solids 355, 885-890.

Biermann U., Friedt W., Lang S., Lühs W., Machmüller G., Metzger J.O., Rüsch gen Klaas M., Schäfer H.J., \& Schneider M.P., (2000) . New Syntheses with Oils and Fats as Renewable Raw Materials for the Chemical Industry. Angewandte Chemie International Edition 39, 2206-2224

Campanella A., Fontanini C., \& Baltanas M-A., (2008). High yield epoxidation of fatty acid methyl esters with performic acid generated in situ. Chemical Engineering Journal 144, 466-475.

Campanella A., \& Baltanas M.A., (2006). Degradation of the oxirane ring of epoxidized vegetable oils in liquid-liquid heterogeneous reaction systems. Chemical Engineering Journal $118,141-152$.

Corma A., Iborra S., \& Velty A., (2007). Chemical Routes for the Transformation of Biomass into Chemicals. Chemical Reviews 107, 2411-2502

Gan L.H., Goh S.H., \& Ooi K.S., (1992). Kinetic studies of epoxidation and oxirane cleavage of palm olein methyl esters. Journal of the American Oil Chemists' Society 69, 347-351.

Gelbard G., Breton F., Quenard M., \& Sherrington D-C., (2000). Epoxidation of cyclohexene with polymethacrylate-based peroxotungstic catalysts. Journal of Molecular Catalysis A: Chemical 153, 7-18.

Giefersa H., Porschb F., \& Wortmann G., (2005). Kinetics of the disproportionation of SnO. Solid State Ionics 176, 199-207.

Goud V. V., Patwardhan A.V., \& Pradhan N.C., (2006a). Studies on the epoxidation of mahua oil (Madhumica indica) by hydrogen peroxide. Bioresource Technology 97, 1365-1371. 
Goud V.V., Pradhan N.C., Patwardhan A.N., (2006b). Epoxidation of karanja (Pongamia glabra) oil by $\mathrm{H} 2 \mathrm{O} 2$. Journal of the American Oil Chemists' Society 83, 635-640

Harry-O'kuru R.E., Gordon S.H., Biswas A., (2005). A facile synthesis of aminohydroxy triglycerides from new crop oils. Journal of the American Oil Chemists'Society 82, 207-212.

Lui F., Quan B., Lui Z., \& Chen L., (2005). Surface characterization study on $\mathrm{SnO} 2$ powder modified by thiourea. Materials Chemistry and Physics 93, 301-304.

Luts T., Frank R., Suprun W., Fritzsche S., HeyHawkins E., \& Papp H., (2007). Epoxidation of olefins catalyzed by novel Mn(III) and Mo(IV)Salen complexes immobilized on mesoporous silica gel Part II: Study of the catalytic epoxidation of olefins. Journal of Molecular Catalysis A: Chemical 273, 250-258.

Monnier J-R., (2001). The direct epoxidation of higher olefins using molecular oxygen. Applied Catalysis A: General 221, 73-91.

Poli E., Clacens J-M., Barrault J., \& Pouilloux Y., (2009), "Solvent-free selective epoxidation of fatty esters over a tungsten-based catalyst", Catalysis Today 140, 19-22.

Rios L.A., Weckes P., Schuster H., \& Hoelderich W.F., (2005). Mesoporous and amorphous Tisilicas on the epoxidation of vegetable oils. Journal of Catalysis 232, 19-26.

Sekizawa K., Widjaja H., Maeda S., Ozawa Y., \& Eguchi K., (2000). Low Temperature of Methane over $\mathrm{Pd} / \mathrm{SnO} 2$ Catalyst. Applied Catalysis A: General 200,211-217.

Sepulveda J., Teixeira S., \& Schuchardt U., (2007). Alumina-catalyzed epoxidation of unsaturated fatty esters with hydrogen peroxide. Applied Catalysis A: General 318, 213-217.

Smith P.J., (1998). Chemistry of Tin, Ed. Blackie Academic \& Professional - Chapman \& Hall, Great Britain, 2nd ed. pp. $35-36,443-475$.

Urresta J., Ramírez A., Martínez C., \& Vargas L., (2000). Transesterificación del aceite de Palma empleando Catalizadores Soportados a base de Sn y Ni. Palmas, 21 No. Especial, 381-385

Verdier S., Didillon B., Morin S., \& Jumas J.C., (2003). Pd-Sn $/ \mathrm{Al}_{2} \mathrm{O}_{3}$ Catalyst from Colloidal Oxide Synthesis. Journal of Catalysis 218, 280287.

Wadumesthrige K., Salley S.O., \& Simon Ng K.Y., (2009). Effects of partial hydrogenation, epoxidation, and hydroxylation on the fuel, properties of fatty acid methyl esters. Fuel Processing Technology 90, 1292-1299.

Wang S., Ma X., \& Yang X., (2004). Transesterification of Dimethyl Oxalate with Phenol under $\mathrm{SnO} 2$ / SiO2 Catalysts. Industrial \& Engineering Chemistry Research 43, 40274030 .

Xi Z., Wang H., Sun Y., Zhou N., Cao G., \& Li M., (2001). Direct epoxidation of olefins catalyzed by heteropolyoxometalates with molecular oxygen and recyclable reductant. Journal of Molecular Catalysis A: Chemical 168, 299-301.

Yang L., He J., Zhang Q., \& Wang Y., (2010). Copper-catalyzed propylene epoxidation by oxygen: Significant promoting effect of vanadium on unsupported copper catalyst. Journal of Catalysis 276, 76-84.

Zaher F.A., El-Mallah M.H., \& El-Hefnawy M.M., (1989). Kinetics of oxirane cleavage in epoxidized soybean oil. Journal of the American Oil Chemists'Society 66, 698-700. 